\title{
Aplotaxene, an Allelochemical from Roots of the Invasive Species Carduus nutans and $C$. acanthoides
}

\author{
AL Cerdeira $\underline{1}$, FML Silva $\underline{2}$, MA Donega $\underline{3}, \mathrm{CL}$ Cantrell $\underline{4}, \mathrm{~K}$ Shea $\underline{\mathbf{5}}$, SO Duke $\underline{4}, \mathrm{~N}$ Corniani $\underline{2}$
}

\author{
${ }^{1}$ Embrapa/Environment, Research Division of Brazilian Department of Agriculture, C.P. 69, Jaguariúna, SP, 13820 - 000 , Brazil \\ ${ }^{2}$ São Paulo State University (UNESP), Fazenda Experimental Lageado, C. P. 237, Botucatu, SP, 18610 - 307, Brazil \\ ${ }^{3}$ University of São Paulo (USP), Avenida Pádua Dias 11, Piracicaba, SP, 13418 - 900, Brasil \\ ${ }^{4}$ USDA-ARS, National Products Utilization Research Unit (NPURU), University, Oxford, MS, 38677 \\ ${ }^{5}$ Department of Biology, Pennsylvania State University, 208 Mueller Laboratory, University Park, PA, 16802 - 5301
}

Congress Abstract (/ejournals/abstract/10.1055/s-0033-1336457)

Carduus nutans L. (musk thistle or nodding thistle), a member of the Asteraceae family, is a Eurasian native plant [1], but is an invasive species in North America, Australia, and New Zealand where it is more competitive in many habitats than in its native area and part of its success may be due to allelopathy [2]. Several secondary compounds have been identified in the genus Carduus. Among them are sterols such as taraxasterol and sitosterol, and flavonoids such as kaempferol, apigenin, and rutin $[3,4,5]$. The objective of this study was to identify the phytotoxic compounds present in Carduus acanthoides and $C$. nutans roots and aerial part by systematically performing bioassay-directed isolation and subsequent identification of the bioactive constituents according to Dayan et al. [6]. No significant phytotoxic activity against Lactuca sativa or Agrostis stolonifera was detected in methanol, or water extracts when tested at $1.0 \mathrm{mg} \cdot \mathrm{mL}^{-1}$; however, the dichlormethane root extract of $C$. acanthoides was active. Further fractionation using hexane:diethyl ether step gradient was performed with the DCM extract. The active compound was isolated and identified by GC-MS and $1 \mathrm{H}-$ and $13 \mathrm{C}-\mathrm{NMR}$. The isolated compound (Figure 1) was identified as the moderately phytotoxic, highly lipophilic compound aplotaxene and was found in roots of both species $C$. canthoides and C. nutans.

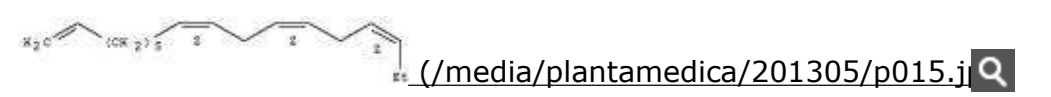

Fig. 1: Isolated compound aplotaxene (CAS Registry Number: 10482 - 53 - 8): 1,8,11,14-

Heptadecatetraene, (Z,Z,Z)-, or (8Z,11Z,14Z)-heptadeca-1,8,11,14-tetraene

Acknowledgements: The authors thank Solomon Green III, Robert Johnson, and Amber Callahan for technical assistance at NPURU, USDA-ARS. References: [1] Desrochers AM, Bain JF, et al. (1988) Can J Plant Sci, 68: 1053 - 1068. [2] Formisano C, Rigano D, et al. (2007)] Plant Interact, 2: 115 - 120. [3] Abdallah OM, Ramadan MA, et al. (1989) Bull Fac Sci Assiut Univ, 18: 69 - 76. [4] Bain JF, Derochers AM (1988) Biochem Syst Ecol, 16: 265 - 268. [5] Kaloshina NA, Mazulin AV (1988) Khim Prir Soedin 3: 453. [6] Dayan FE, Romagni JG, et al. (2000)J Chem Ecol 26: 2079 - 2094. 